\title{
Proteomic profiling of microbial transglutaminase-induced polymerization of milk proteins
}

\author{
J. F. Hsieh ${ }^{1}$ and P. H. Pan \\ Department of Food Science, Fu Jen Catholic University, Xin Zhuang, Taipei 242, Taiwan
}

\begin{abstract}
Microbial transglutaminase (MTGase)-induced polymerization of individual milk proteins during incubation was investigated using a proteomics-based approach. The addition of MTGase (0.25-2.0 units/mL) caused the milk proteins to polymerize after a 3 -h incubation period. Sodium dodecyl sulfate-PAGE analysis showed that the total intensities of the protein bands that corresponded to $\alpha_{\mathrm{S}}$-casein, $\beta$-casein, and $\kappa$-casein decreased from 8,245.6, 6,677.2, and 586.6 arbitrary units to $1,911.7,0.0$, and 66.2 arbitrary units, respectively. Components with higher molecular weights were observed, and the intensity of these proteins increased after $3 \mathrm{~h}$ of incubation. These results support that inter- or intramolecular crosslinking occurred in the casein proteins of MTGase-treated milk. Two-dimensional electrophoresis analysis indicated that isomers of $\beta$-casein, $\kappa$-casein, a fraction of serum albumin, $\alpha_{\mathrm{S} 1^{-}}$ casein, $\alpha_{S 2}$-casein, $\beta$-lactoglobulin, and $\alpha$-lactalbumin in the milk were polymerized following incubation with MTGase. In addition, MTGase-induced polymerization occurred earlier for $\beta$-casein and $\kappa$-casein isomers than for other milk proteins.
\end{abstract}

Key words: transglutaminase, milk protein, twodimensional electrophoresis, proteomics

\section{INTRODUCTION}

Transglutaminase (TGase; EC 2.3.2.13) is an enzyme that catalyzes an acyl transfer reaction between the $\gamma$-carboxyamide of a protein-bound glutamine residue and a primary amine (Agyare and Damodaran, 2010). Transglutaminase is widely distributed in animal tissues, plants, and microorganisms. The extracellular microbial TGase (MTGase) from Streptovercillium mobaraense has become commercially available (Gerber et al., 1994). As MTGase can form intra- and intermolecular crosslinks, large-molecular-weight (MW) polymers with altered functionality are produced. Milk pro-

Received July 27, 2011.

Accepted October 23, 2011.

${ }^{1}$ Corresponding author: 075101@mail.fju.edu.tw teins have been shown to be substrates for crosslinking by MTGase and have attracted considerable attention in dairy research (Monogioudi et al., 2009). Caseins appear to be readily crosslinked by MTGase because of their flexible random-coil structures and the absence of disulfide bonds in $\alpha_{\mathrm{S}^{-}} \mathrm{CN}$ and $\beta-\mathrm{CN}$ (O'Connell and Fox, 2000; Moon et al., 2009).

Microbial TGase can modify solubility, hydration, and heat stability of caseins, as well as their gelation, rheological, emulsifying, and renneting properties (Lorenzen et al., 2002). O'Sullivan et al. (2002) suggested that the treatment of milk with MTGase improves its heat stability, which is probably accomplished by preventing dissociation of $\mathrm{k}-\mathrm{CN}$ from micelles by crosslinking the caseins. Microbial TGase is a calciumindependent enzyme that can catalyze the formation of covalent $\varepsilon$ - $(\gamma$-glutamyl $)$ lysine crosslinks, which is important in improving the functional properties of milk proteins without loss of nutritional quality (Czernicka et al., 2009). However, some researchers reported the crosslinking of whey proteins such as $\beta$-LG when milk was treated with MTGase. The whey proteins tend to crosslink less efficiently than caseins because of their compact globular structures (Matsumura et al., 2000).

Recently, a proteomics approach has been used to study the milk proteins (Holland et al., 2011). Proteomics has emerged as a novel experimental approach to analyze several hundred proteins in complex mixtures using high-resolution 2-dimensional gel electrophoresis (2-DE) coupled with mass spectrometry (Gagnaire et al., 2009). In this method, proteins are separated according to their isoelectric point $(\mathbf{p} \boldsymbol{I})$ along a $\mathrm{pH}$ gradient by isoelectric focusing in the first dimension and according to their molecular weight by SDS-PAGE in the second dimension (Ong and Pandey, 2001). All protein spots that are resolved and detected can be qualitatively and quantitatively studied in relation to each other (Bahrman et al., 2004). Therefore, 2-DE combined with mass spectrometry has been used to separate and identify individual milk proteins of interest. However, the proteomics analysis of MTGase-induced polymerization of individual milk proteins during incubation has never been reported. In this study, we used SDS-PAGE and 2-DE coupled with MS to investigate 
the effects of MTGase on the polymerization of milk proteins. The objective of this study was to analyze MTGase-induced polymerization of milk proteins using a proteomics approach.

\section{MATERIALS AND METHODS}

\section{Preparation of Milk Samples}

Fresh raw milk from a healthy Holstein-Friesian cow was obtained from a local farm in Taipei in northern Taiwan. The milk was skimmed at 5,000 $\times g$ for $20 \mathrm{~min}$, and the skim milk $(23.8 \mathrm{mg} / \mathrm{mL})$ was collected and stored at $4^{\circ} \mathrm{C}$. Microbial TGase from Streptoverticillium mobaraense (1 unit/mg) was obtained from Ajinomoto Co. Inc. (Activa TG-B, solution form; Ajinomoto Co. Inc., Tokyo, Japan). To investigate the effects of MTGase on the polymerization of milk proteins, milk samples with varying amounts of MTGase $(0,0.25,0.5$, 1.0 , or 2.0 units $/ \mathrm{mL}$ ) were incubated at $30^{\circ} \mathrm{C}$ for $3 \mathrm{~h}$. The resulting samples were heated to $80^{\circ} \mathrm{C}$ for $3 \mathrm{~min}$ to inactivate the MTGase. In this study, MTGase-induced polymerization of milk proteins during incubation was studied. The milk samples with $(2.0$ units $/ \mathrm{mL})$ or without MTGase were incubated at $30^{\circ} \mathrm{C}$ for $0,1,2$, or $3 \mathrm{~h}$.

\section{SDS-PAGE Analysis}

Milk samples with or without MTGase were analyzed by SDS-PAGE according to Hsieh and Chen (2008) and using a $12.5 \%$ separating gel and a 5\% stacking gel. For each sample, $0.1 \mathrm{~mL}$ was mixed with $0.9 \mathrm{~mL}$ of buffer (2\% SDS, $5 \% \beta$-mercaptoethanol, $10 \%$ glycerol, $0.02 \%$ bromophenol blue, and $70 \mathrm{~m} M$ Tris-HCl, $\mathrm{pH}$ 6.8) and heated to $95^{\circ} \mathrm{C}$ for $5 \mathrm{~min}$. The samples and a protein ladder were loaded into separate wells $(6 \mu \mathrm{L} /$ well). Following electrophoresis, the gels were stained with Coomassie Brilliant Blue R-250. The stained gels were digitized using an Epson perfection 1270 image scanner (Epson America Inc., Long Beach, CA) and analyzed using Quantity One 1-D analysis software (version 4.6.3, Bio-Rad, Hercules, CA) and Gel-Pro Analyzer software (version 4.0, Media Cybernetics Inc., Bethesda, MD). Changes in the electrophoretic profiles were used to evaluate protein polymerization induced by MTGase.

\section{2-DE PAGE}

Milk samples were analyzed by 2-DE. For the first separation, $100 \mu \mathrm{g}$ of total milk protein was immobilized and loaded onto $\mathrm{pH}$ gradient (immobilized $\mathrm{pH}$ gradient, IPG) gel strips ( $\mathrm{pH} 4-7,18 \mathrm{~cm}$; GE Healthcare, Burr Ridge, IL) that had been rehydrated for 12 $\mathrm{h}$ in a solution containing $7 M$ urea, $2 M$ thiourea, $4 \% 3$-[(3-cholamidopropyl)-dimethylammonio]-1-propanesulfonate, $40 \mathrm{~m} M$ Tris-base, $2 \%$ IPG ampholyte, $65 \mathrm{mM}$ 1,4-dithioerythritol (DTE), and $0.0002 \%$ bromophenol blue. Isoelectric focusing of the IPG strips was performed using the IPGphor 3 IEF system (GE Healthcare) at $20^{\circ} \mathrm{C}$ and $6,000 \mathrm{~V}$ for a total of $60 \mathrm{kVh}$. The strips were equilibrated for $15 \mathrm{~min}$ in equilibration solution (50 mM Tris- $\mathrm{HCl}, \mathrm{pH} 8.8,6 \mathrm{M}$ urea, $2 \%$ SDS, $30 \%$ glycerol, and $2 \%$ DTE) and added to the top of a vertical $12.5 \%$ SDS-PAGE gel with $0.5 \%$ agarose. The second electrophoresis step was performed using a Protean II xi Cell system (Bio-Rad) at $10 \mathrm{~mA}$ per gel for $1 \mathrm{~h}$ followed by $45 \mathrm{~mA}$ per gel for $5 \mathrm{~h}$ until the bromophenol blue reached the bottom of the gel. After electrophoresis, the gels were immersed in $10 \%$ methanol and $7 \%$ acetic acid for $30 \mathrm{~min}$ and were stained in $350 \mathrm{~mL}$ of Sypro Ruby protein gel stain solution (Molecular Probes Inc., Eugene, OR) overnight (Berggren et al., 2000). The developed gels were digitally scanned as 2-D images with a Typhoon 9200 imaging system (Amersham Pharmacia Biotech Inc., Piscataway, NJ) and analyzed using the PDQuest software package (version 7.3, Bio-Rad).

\section{Protein Digestion and MS Analysis}

Twenty-one selected milk protein spots were excised and destained by two 15-min washes in a solution that contained $250 \mu \mathrm{L}$ of acetonitrile/50 $\mathrm{mM}$ ammonium bicarbonate $(1: 1 \mathrm{vol} / \mathrm{vol})$. The gels were dried using a centrifugal vacuum concentrator. The cysteine residues in the samples were reduced and alkylated using DTE and iodoacetamide, respectively. For tryptic digestion, the gels were rehydrated in a trypsin solution (12.5 $\mathrm{ng} / \mathrm{mL}$ ) and incubated at $37^{\circ} \mathrm{C}$ for $16 \mathrm{~h}$. Peptide fragments were extracted with an equal volume of $100 \%$ acetonitrile and $2 \%$ trifluoroacetic acid and sonicated in a water bath for $10 \mathrm{~min}$. The extracted peptides were concentrated in a vacuum centrifuge. For matrixassisted laser desorption/ionization-mass spectrometry (MALDI-MS) analysis, the extracted peptides were mixed 1:1 with a matrix solution $(5 \mathrm{mg} / \mathrm{mL}$ of $\alpha$-cyano4-hydroxycinnamic acid in $50 \%$ acetonitrile, $0.1 \% \mathrm{vol} /$ vol trifluoroacetic acid, and $2 \% \mathrm{wt} / \mathrm{vol}$ ammonium citrate) and spotted onto a 96-well format MALDI sample stage. Data were directly obtained using a quadrupole time-of-flight (Q-TOF) Ultima MALDI instrument (MALDI, Micromass, Manchester, UK).

\section{Protein Identification}

Peptide mass fingerprint data from MALDI-Q-TOF analyses were used to identify protein candidates in the 


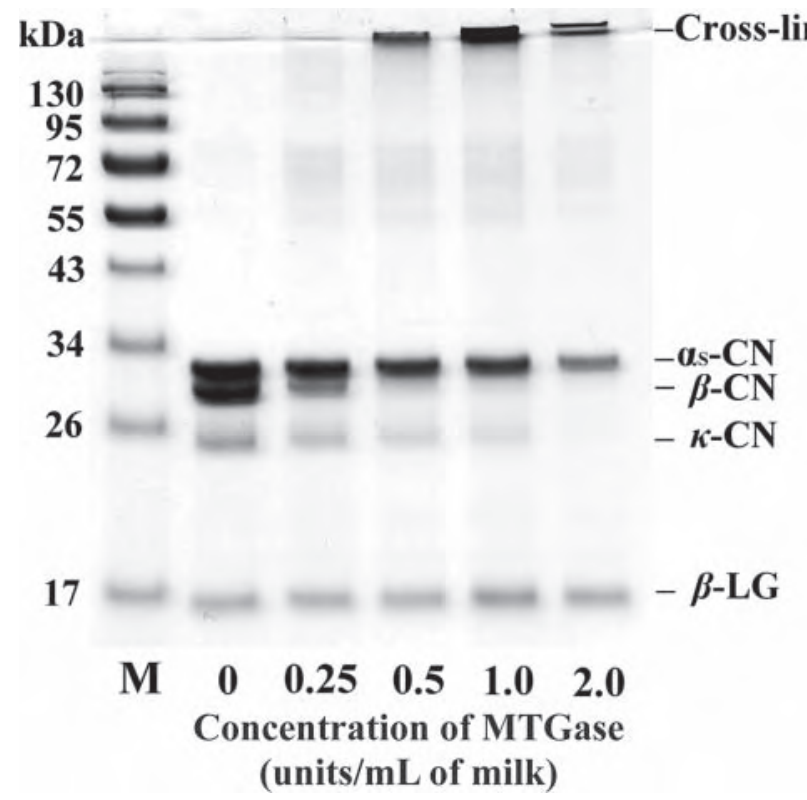

Figure 1. Changes in SDS-PAGE profiles of milk proteins with varying amounts of microbial transglutaminase (MTGase) incubated at $30^{\circ} \mathrm{C}$ for $3 \mathrm{~h} . \mathrm{M}=$ protein marker.

Swiss-Prot protein databases (http://www.expasy.ch/ sprot) using the Mascot (http://www.matrixscience. com) search program (Gygi and Aebersold, 2000).
Search parameters allowed for methionine oxidation, cysteine carbamidomethylation, one missed cleavage site, and a peptide mass tolerance of $0.25 \mathrm{Da}$ (Morrissey and Downard, 2006). The product ion spectra generated by Q-TOF MS/MS were compared with those in the Swiss-Prot protein database, and an exact match was found using the Mascot search program (Ahram et al., 2002).

\section{RESULTS AND DISCUSSION}

\section{Effects of MTGase on the Crosslinking of Milk Proteins}

Microbial TGase is an acyltransferase that forms intra- and intermolecular crosslinks by isopeptide bond formation between peptide-bound glutamine and lysine residues (Garcia et al., 2007). Milk samples were incubated with various amounts of MTGase $(0,0.25,0.5$, 1.0 , or 2.0 units $/ \mathrm{mL}$ ) for a 3 -h period and analyzed by SDS-PAGE. The polymerization of $\beta-\mathrm{CN}, \kappa-\mathrm{CN}$, and a portion of $\alpha_{S}-\mathrm{CN}$ by MTGase into higher $\mathrm{MW}$ proteins was observed. The increase in high MW proteins of $200 \mathrm{kDa}$ is shown in Figure 1, as evidenced by the increase in protein staining intensity at the top of the gels, which positively correlated with increasing amounts of MTGase. The components with higher MW
A

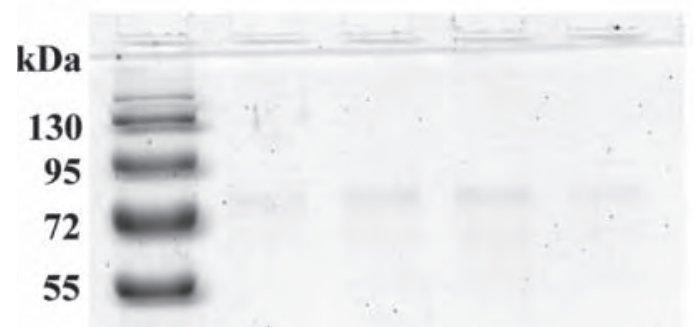

43

34

26

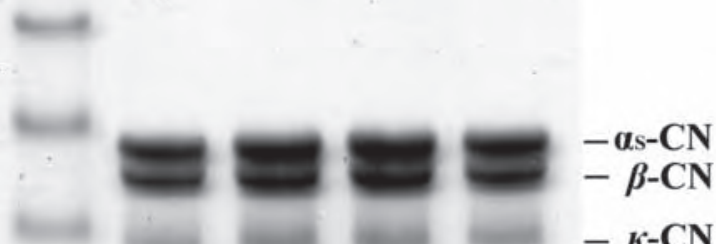

17

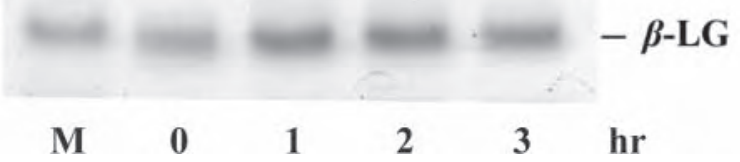

B

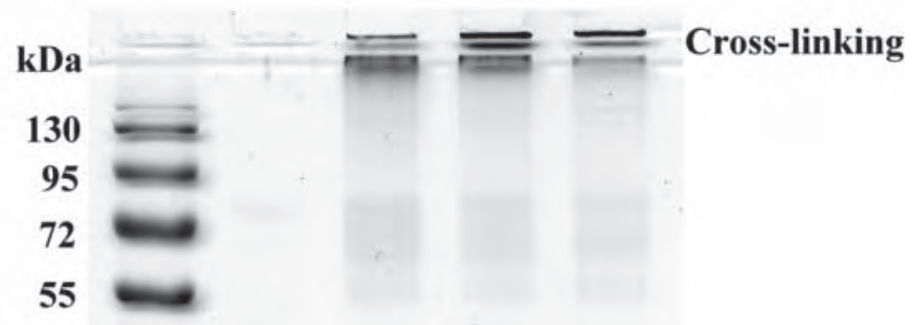

43

34
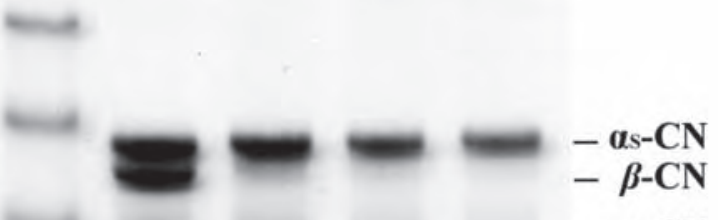

26

$-\kappa-\mathrm{CN}$

17

$-\beta$-LG

$\begin{array}{llllll}M & \mathbf{0} & \mathbf{1} & \mathbf{2} & \mathbf{3} & \mathrm{hr}\end{array}$

Figure 2. Changes in the SDS-PAGE profiles of milk proteins incubated with and without microbial transglutaminase $(\mathrm{MTGase})$ at $30^{\circ} \mathrm{C}$ for varying amounts of time. (A) Milk without MTGase; (B) milk with 2.0 units of MTGase/mL; M = protein marker. 
likely resulted from casein $\left(\alpha_{S^{-}} \mathrm{CN}, \beta-\mathrm{CN}\right.$, and $\left.\kappa_{-} \mathrm{CN}\right)$ crosslinking. In addition, the staining intensity of $\beta-\mathrm{CN}$ and $\kappa-\mathrm{CN}$ decreased when 0.25 and $1.0 \mathrm{units} / \mathrm{mL}$ of MTGase were added, respectively, and the $\beta-\mathrm{CN}$ and $\kappa-\mathrm{CN}$ bands almost disappeared after the addition of 2.0 units/mL of MTGase. The disappearance of $\beta-\mathrm{CN}$ and $\kappa$-CN confirmed the presence of casein crosslinking because the $\varepsilon$ - $(\gamma$-glutamyl $)$ lysine isopeptide bonds formed in the crosslinked caseins by MTGase are difficult to dissociate using SDS and mercaptoethanol during SDS-PAGE analysis (Abd-Rabo et al., 2010). These results demonstrated that $\beta-\mathrm{CN}$ and $\kappa-\mathrm{CN}$ were crosslinked more readily by MTGase than was $\beta$-LG. However, $\beta$-LG could still be observed after the addition of 2.0 units/mL MTGase. De Jong and Koppelman (2002) indicated that $\beta$-LG is a major globular whey protein, and globular proteins are poor substrates for MTGase because their active sites are rarely exposed (Tang and Ma, 2007).

\section{Effects of Incubation Time on the Crosslinking of Milk Proteins by MTGase}

Milk samples with or without MTGase (2.0 units/ $\mathrm{mL}$ ) were incubated at $30^{\circ} \mathrm{C}$ for 1,2 , or $3 \mathrm{~h}$ before analysis by SDS-PAGE (Figure 2). No significant changes were observed in the milk samples without MTGase treatment after a 3 -h incubation period, indicating that protein polymerization did not occur in the absence of MTGase (Figure 2A). However, the amount of casein $\left(\alpha_{\mathrm{S}}-\mathrm{CN}, \beta-\mathrm{CN}\right.$, and $\left.\kappa-\mathrm{CN}\right)$ in the MTGase-treated milk decreased with increasing incubation time (Figure 2B). As previously mentioned, the disappearance of caseins suggests the occurrence of polymerization because MTGase catalyzes an acyl transfer reaction between the $\gamma$-carboxyamide of a peptide- or protein-bound glutamine residue and a primary amine. de Kruif and Holt (2003) reported that the polymerization of $\beta-\mathrm{CN}$ and $\kappa-\mathrm{CN}$ induced by MTGase may be due to the specific location of the enzyme within the casein micelle, and the flexible conformation of caseins may promote catalysis by MTGase (Lee et al., 2002). Furthermore, SDS-PAGE demonstrated that the MTGase-induced crosslinking of $\beta-\mathrm{CN}$ and $\kappa-\mathrm{CN}$ was considerably faster than that of $\alpha_{S^{-}} \mathrm{CN}$. The susceptibility of $\alpha_{S^{-}} \mathrm{CN}$ to catalysis by MTGase was lower than that of $\beta-\mathrm{CN}$ and $\kappa-\mathrm{CN}$, which has been observed in several previous studies (Huppertz and de Kruif, 2007). The densitograms that correspond to SDS-PAGE analysis of the MTGase-containing milk samples are shown in Figure 3. The total intensity of the protein bands that correspond to $\alpha_{S^{-}} \mathrm{CN}, \beta-\mathrm{CN}$, and ${ }^{\kappa}-\mathrm{CN}$ in the milk were 8,245.6, 6,677.2, and 586.6 arbitrary units (AU), respectively (Figure 3). Morris et al. (2000) reported that $\alpha_{S}-\mathrm{CN}, \beta-\mathrm{CN}$, and $\kappa-\mathrm{CN}$ are present in milk at a ratio of approximately 5:4:1. After the incubation of MTGase-containing milk for 3 $\mathrm{h}$, the total intensity of $\alpha_{\mathrm{S}}-\mathrm{CN}, \beta-\mathrm{CN}$, and $\kappa-\mathrm{CN}$ in the milk decreased from 8,245.6, 6,677.2, and 586.6 AU to 1,911.7, 0.0, and 66.2 AU, respectively.

\section{Identification of Milk Proteins by 2-DE Analysis}

O'Donnell et al. (2004) reported that 2-DE combined with MS could be used to identify milk proteins. The 2-DE image of milk proteins is shown in Figure 4. Twenty-one spots selected from the 2-DE gel were digested with trypsin, and the resulting peptides were analyzed by MS. These proteins were identified by comparison with mammalian protein sequences in the Swiss-Prot databases. In total, 21 proteins were assigned individual numbers and cataloged according to their MW and $\mathrm{p} I$ (Table 1). The identified proteins were grouped into isomers of BSA, $\alpha_{\mathrm{S}_{1}} \mathrm{CN}, \alpha_{\mathrm{S} 2}-\mathrm{CN}$, $\beta-\mathrm{CN}, \kappa-\mathrm{CN}, \beta-\mathrm{LG}$, and $\alpha-\mathrm{LA}$. The identified proteins were consistent with those identified by Chevalier et al. (2009). Spots 1 to 3 were isomers of BSA, spots 19 and 20 were isomers of $\beta-\mathrm{LG}$, and spot 21 was $\alpha-\mathrm{LA}$; BSA, $\beta-\mathrm{LG}$, and $\alpha-\mathrm{LA}$ are major components of whey protein isolates (Elshereef et al., 2010). Moreover, spots 4 to 6 , 7 to 9,10 to 12 , and 13 to 18 were isomers of $\alpha_{\mathrm{S} 1}-\mathrm{CN}$, $\alpha_{\mathrm{S} 2^{-}} \mathrm{CN}, \beta-\mathrm{CN}$, and $\kappa-\mathrm{CN}$, respectively. We observed multiple spots for $\alpha_{\mathrm{S}^{-}} \mathrm{CN}, \alpha_{\mathrm{S}^{-}} \mathrm{CN}, \beta-\mathrm{CN}, \kappa-\mathrm{CN}$, and $\beta-\mathrm{LG}$ on the 2-DE gel. Holland et al. (2004) reported that multiple protein forms on a 2-DE gel indicate the presence of co- and posttranslational modifications, which cause a shift in the MW. Phosphorylation or glycosylation can modify the molecular weight or $\mathrm{p} I$ of a protein (Barrabés et al., 2010). In addition, protein degradation may be responsible for multiple spots of the same protein. Chevalier et al. (2009) reported that caseins comprise $80 \%$ of milk proteins and are present in various forms that depend on varying glycosylation patterns and levels of degradation.

\section{2-DE Analysis of the Effects of MTGase on Caseins and Whey Proteins}

Milk samples with (2.0 units/mL) or without MTGase were incubated at $30^{\circ} \mathrm{C}$ for 1,2 , or $3 \mathrm{~h}$ before analysis by 2-DE gels (Figure 5). According to the 2 -DE results, the $\beta$-CN isomers (spots 10-12) in the MTGase-treated milk were almost depleted after $1 \mathrm{~h}$ of incubation. However, a portion of the $\alpha_{\mathrm{S}^{-}} \mathrm{CN}$ isomers (spots $4-6), \alpha_{\mathrm{S}_{2}} \mathrm{CN}$ isomers (spots $7-9$ ), and $\kappa-\mathrm{CN}$ isomers (spots 13-18) disappeared after $2 \mathrm{~h}$ of incubation. We noticed that the profile of spot 4 was different from that of spot 6 (both $\alpha_{\mathrm{S} 1}-\mathrm{CN}$ ). Spot 4 had a high fold change, which may have been dependent on a lower 

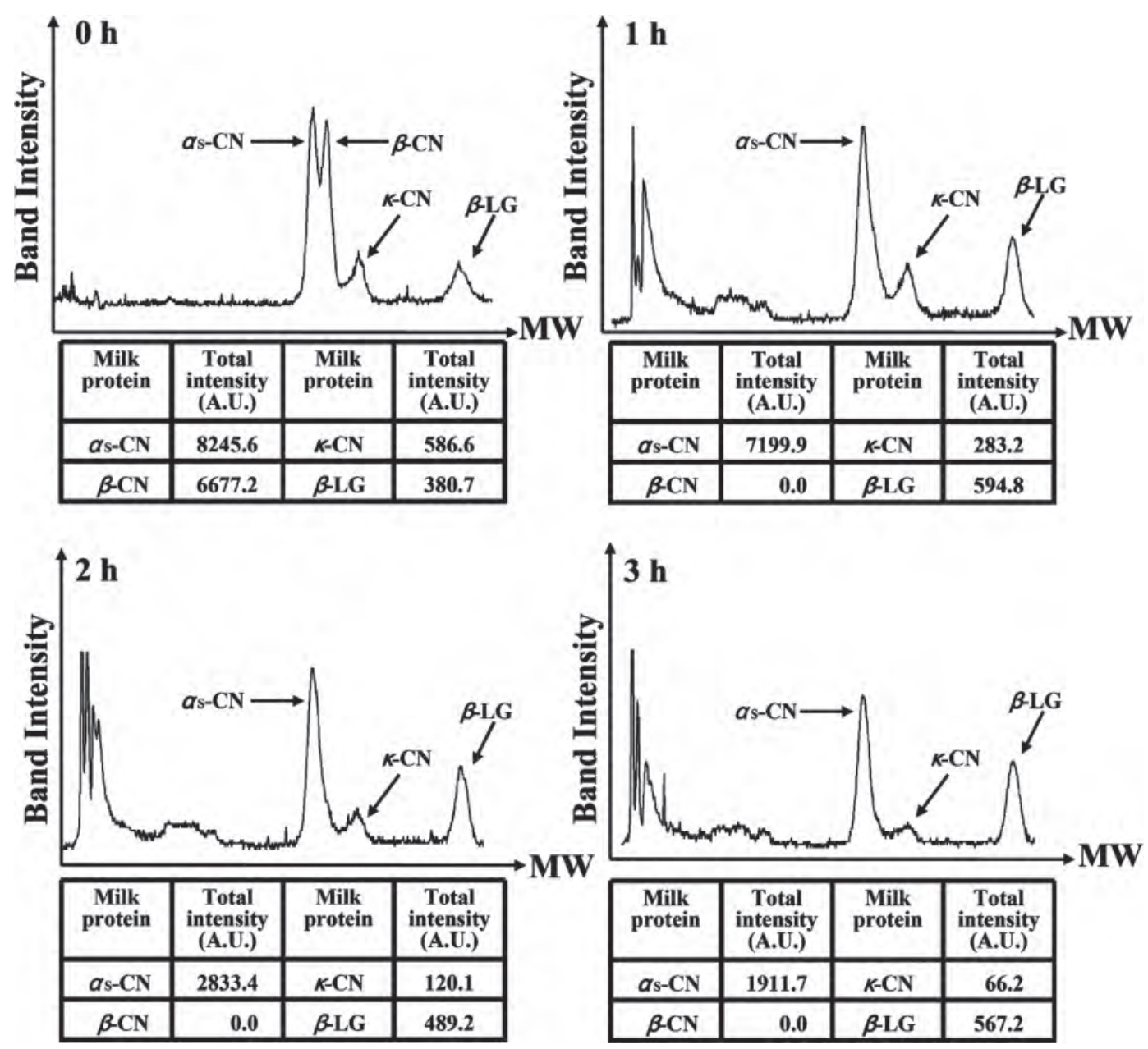

Figure 3. Densitograms corresponding to SDS-PAGE analysis of milk proteins with microbial transglutaminase (MTGase; 2.0 units/mL) incubated at $30^{\circ} \mathrm{C}$ for varying amounts of time. The results were expressed in arbitrary units $(\mathrm{AU})$. MW = molecular weight.

concentration from the beginning. Furthermore, we also noticed that the profile of spot 13 was different from that of spot 16 (both $\kappa-\mathrm{CN}$ ). Pisano et al. (1994) reported that $\kappa-\mathrm{CN}$ is a glycoprotein and that the $O$ glycosylation sites are in the C-terminal portion of the molecule. Similar to the results of Holland et al. (2005), spots 13 and 16 were identified as being triglycosylated and monoglycosylated $\kappa$-CN, respectively. According to our results, spot 16 had a higher fold change than spot 13 , which suggests that monoglycosylated $\kappa$-CN is an excellent substrate for MTGase. During incubation, we observed that casein crosslinking rates were in the following order: $\beta-\mathrm{CN}>\kappa-\mathrm{CN}>\alpha_{\mathrm{S} 1}-\mathrm{CN}$ and $\alpha_{S 2}-\mathrm{CN}$. Bönisch et al. (2007) reported that the casein proteins possess a highly accessible and flexible open chain structure that makes them favorable substrates for MTGase. Furthermore, the amino acid sequence of $\beta$-CN contains 11 lysines and 20 glutamines, which makes it a better substrate for MTGase than $\alpha_{S 1}$ CN and $\alpha_{\mathrm{S}_{2}} \mathrm{CN}$ (Monogioudi et al., 2009). After incubation of milk with MTGase for $3 \mathrm{~h}, \beta-\mathrm{CN}$ (spots 10-12) and $\kappa$-CN (spots 13-18) isomers were almost completely polymerized by MTGase, whereas the BSA (spots 1-3), $\alpha_{\mathrm{S}^{-}} \mathrm{CN}$ (spots 4-6), $\alpha_{\mathrm{S} 2}-\mathrm{CN}$ (spots 7-9), $\beta-\mathrm{LG}$ (spots 19-20), and $\alpha$-LA (spot 21) isomers were still clearly visible on the 2-DE gels. Lee et al. (2002) reported that whey proteins such as BSA, $\beta-\mathrm{LG}$, and $\alpha-\mathrm{LA}$ are globular proteins that are poor substrates for MTGase.

Densitograms corresponding to the 2-DE images of the MTGase-treated milk samples were generated and the fold changes of individual milk proteins are shown in Figure 6. The fold changes of $\beta-\mathrm{CN}$ and $\kappa-\mathrm{CN}$ isomers in the MTGase-treated milk decreased significantly with incubation time. The $\beta-\mathrm{CN}$ isomers in the MTGase-treated milk almost disappeared after $3 \mathrm{~h}$ of incubation (Figure 6A). The changes of spot 10 $(\beta-\mathrm{CN})$, spot $11(\beta-\mathrm{CN})$, and spot $12(\beta-\mathrm{CN})$ in the MTGase-treated milk were 0.007-, 0.027-, and 0.023- 
Table 1. Milk proteins identified and cataloged according to 2-dimesional gel electrophoresis analysis

\begin{tabular}{|c|c|c|c|c|c|c|}
\hline Spot no. ${ }^{1}$ & $\begin{array}{l}\text { Entry } \\
\text { name }^{2}\end{array}$ & $\begin{array}{l}\text { Protein } \\
\text { name }\end{array}$ & \multicolumn{2}{|c|}{$\mathrm{MW}(\mathrm{Da}) / \mathrm{p} I^{3}$} & $\begin{array}{l}\text { Mowse } \\
\text { score }\end{array}$ & $\begin{array}{c}\text { Coverage } \\
(\%)\end{array}$ \\
\hline 1 & ALBU_BOVIN & Serum albumin & $72,000 / 5.8$ & $69,248 / 5.82$ & 132 & 11 \\
\hline 3 & ALBU_BOVIN & Serum albumin & $72,000 / 6.0$ & $69,248 / 5.82$ & 118 & 8 \\
\hline 4 & CASA1_BOVIN & $\alpha_{\mathrm{S}^{2}}-\mathrm{CN}$ & $31,000 / 4.1$ & $24,513 / 4.98$ & 143 & 15 \\
\hline 5 & CASA1_BOVIN & $\alpha_{S_{2}-} \mathrm{CN}$ & $34,000 / 4.2$ & $24,513 / 4.98$ & 236 & 20 \\
\hline 9 & CASA2_BOVIN & $\alpha_{\mathrm{S} 2}-\mathrm{CN}$ & $32,000 / 5.0$ & $26,002 / 8.54$ & 40 & 8 \\
\hline 10 & CASB_BOVIN & $\beta-\mathrm{CN}$ & $30,000 / 4.7$ & $25,091 / 5.26$ & 61 & 8 \\
\hline 11 & CASB_BOVIN & $\beta-\mathrm{CN}$ & $30,000 / 4.8$ & $25,091 / 5.26$ & 60 & 8 \\
\hline 12 & CASB_BOVIN & $\beta-\mathrm{CN}$ & $30,000 / 4.9$ & $25,091 / 5.26$ & 84 & 8 \\
\hline 13 & CASK_BOVIN & $\kappa-\mathrm{CN}$ & $28,000 / 4.6$ & $21,256 / 6.30$ & 37 & 12 \\
\hline 14 & CASK_BOVIN & $\kappa-\mathrm{CN}$ & $28,000 / 4.8$ & $21,256 / 6.30$ & 46 & 5 \\
\hline 20 & LACB_BOVIN & $\beta-\overline{L G}$ & $20,000 / 4.9$ & $19,870 / 4.93$ & 179 & 46 \\
\hline 21 & LALBA_BOVIN & $\alpha-\overline{L A}$ & $14,000 / 4.8$ & $16,264 / 4.81$ & 80 & 24 \\
\hline
\end{tabular}

${ }^{1}$ Spot no. $=$ spot number corresponding to Figure 4 . The method used for protein identification was MS/MS for all spot no. and bovines were the source for all proteins.

${ }^{2}$ Protein name in the Swiss-Prot protein databases.

${ }^{3} \mathrm{MW}=$ molecular weight; $\mathrm{p} I=$ isoelectric point.

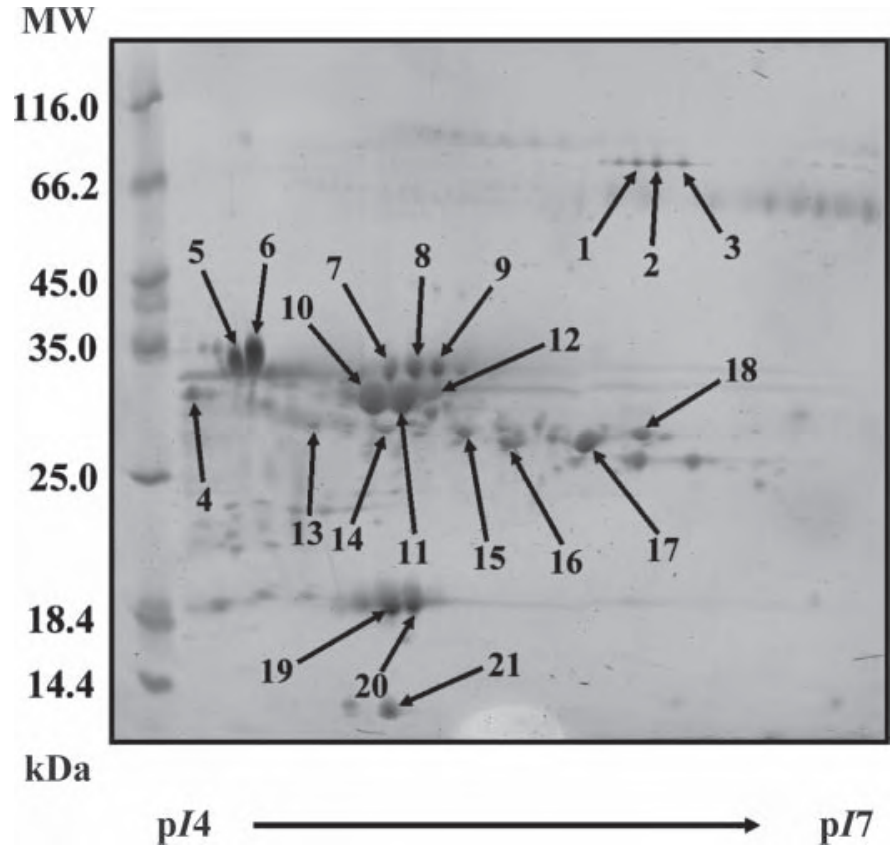

Figure 4. 2-Dimensional gel electrophoresis analysis of milk proteins. Milk proteins were separated on a $12.5 \%$ SDS-PAGE gel using immobilized pH gradient (IPG; pH 4-7, GE Healthcare, Burr Ridge, IL) strips. The arrows indicate the protein spots that were identified in this study. $\mathrm{MW}=$ molecular weight; $\mathrm{p} I=$ isoelectric point. fold, respectively. This analysis revealed that $99.3 \%$ of spot $10(\beta-\mathrm{CN}), 97.3 \%$ of spot $11(\beta-\mathrm{CN})$, and $97.7 \%$ of spot $12(\beta-\mathrm{CN})$ were polymerized by MTGase after $3 \mathrm{~h}$ of incubation. Moreover, the $\mathrm{\kappa}-\mathrm{CN}$ isomers in the MTGase-treated milk were almost depleted after $3 \mathrm{~h}$ of incubation (Figure $6 \mathrm{~B}$ ). The changes of spots 13 to $18(\kappa-\mathrm{CN})$ in the MTGase-treated milk were 0.080-, 0.057-, 0.067-, 0.037-, 0.093-, and 0.040-fold, respectively. These results showed that the $\beta-\mathrm{CN}$ and $\kappa-\mathrm{CN}$ isomers were effective substrates for MTGase. However, only a portion of BSA (spots 1-3), $\alpha_{\mathrm{S}_{1}} \mathrm{CN}$ (spots 4-6), $\alpha_{\mathrm{S}_{2}} \mathrm{CN}$ (spots $7-9$ ), $\beta-\mathrm{LG}(\operatorname{spots} 19-20)$, and $\alpha-\mathrm{LA}$ (spot 21) isomers were polymerized by MTGase after 3 $\mathrm{h}$ of incubation.

\section{Reaction Scheme for the Effect of MTGase on Milk Proteins}

Based on our results, a reaction scheme for the effect of MTGase on the polymerization of individual milk proteins is shown in Figure 7. The MTGase-mediated polymerization reaction includes 2 steps, the first being an enzymatic process in which MTGase catalyzes $\beta$-CN and $\kappa-\mathrm{CN}$. Microbial TGase-induced polymerization occurs more readily for $\beta-\mathrm{CN}$ and $\kappa-\mathrm{CN}$ than for other milk proteins, which may be an effect of the specific location of MTGase within the casein micelle (de Kruif 

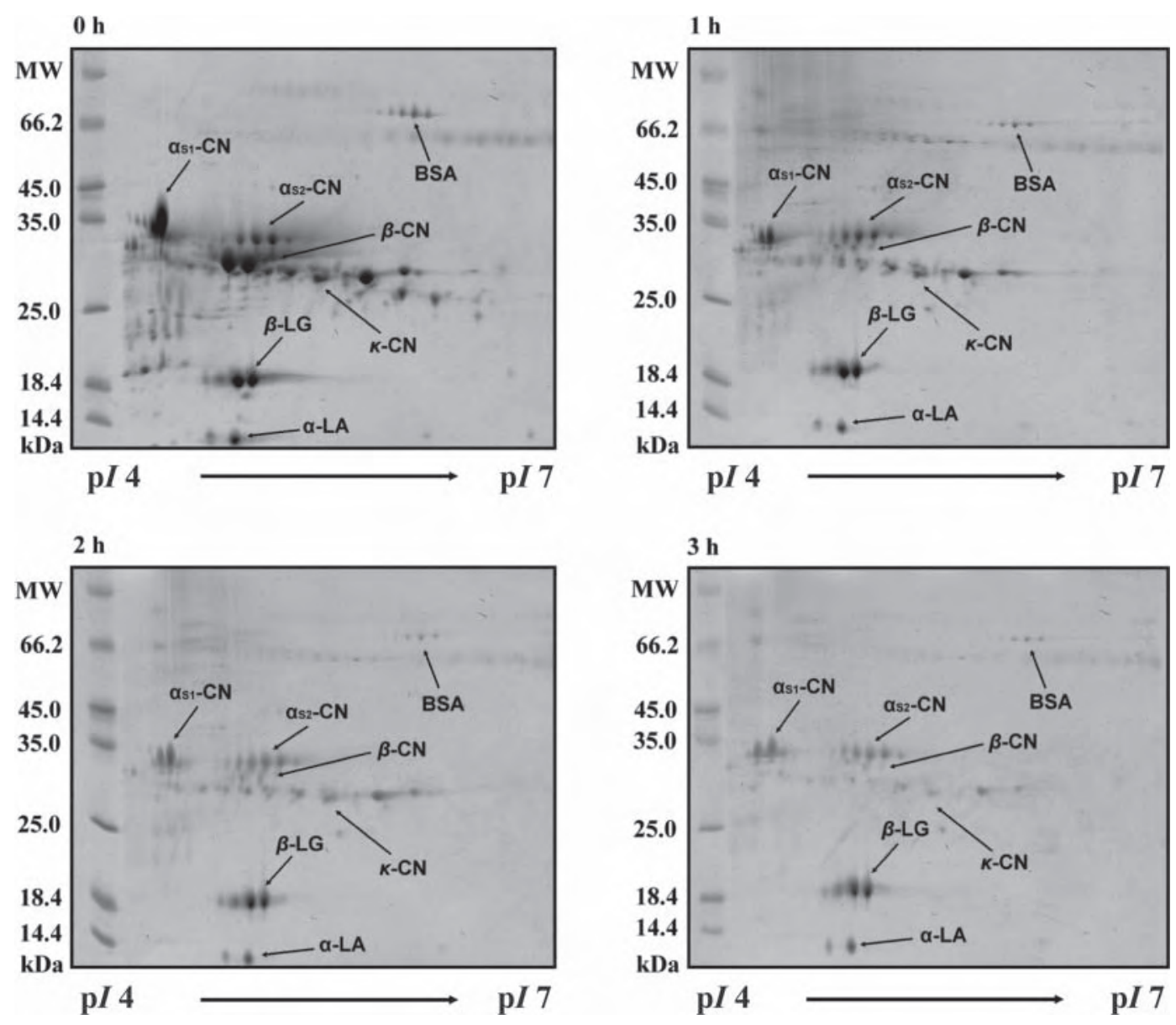

Figure 5. Changes in the 2-dimensional gel electrophoresis profiles of milk proteins after treatment with microbial transglutaminase (MTGase; 2.0 units $/ \mathrm{mL}$ ) at $30^{\circ} \mathrm{C}$ for various lengths of time. $\mathrm{MW}=$ molecular weight; $\mathrm{p} I=$ isoelectric point.

and Holt, 2003). It is known that $\alpha_{\mathrm{S}^{-}} \mathrm{CN}, \alpha_{\mathrm{S} 2}-\mathrm{CN}$, $\beta-\mathrm{CN}$, and $\kappa-\mathrm{CN}$ are incorporated into casein micelles; however, some $\beta-\mathrm{CN}$ and $\kappa-\mathrm{CN}$ molecules are located in the outer region of casein micelles and are more readily catalyzed by MTGase (Smiddy et al., 2006). Furthermore, Sharma et al. (2001) reported that the porous nature of casein micelles allows MTGase to diffuse into the interior. Therefore, the flexible conformation of $\beta-\mathrm{CN}$ in casein micelles also allows for catalysis by MTGase. The second step involves MTGase-mediated catalysis of $\alpha_{\mathrm{S}^{-}} \mathrm{CN}, \alpha_{\mathrm{S}^{-}} \mathrm{CN}$, and whey proteins. In our study, a portion of BSA, $\alpha_{\mathrm{S}_{1}-} \mathrm{CN}, \alpha_{\mathrm{S} 2^{-}} \mathrm{CN}, \beta-\mathrm{LG}$, and $\alpha$-LA were catalyzed by MTGase. However, the degree of polymerization of $\alpha_{\mathrm{S}_{1}} \mathrm{CN}, \alpha_{\mathrm{S}_{2}} \mathrm{CN}$, and whey proteins was less than that of $\beta-\mathrm{CN}$ and $\kappa-\mathrm{CN}$. The aggregated milk proteins contained $\beta-\mathrm{CN}, \kappa-\mathrm{CN}$, and a portion of the BSA, $\alpha_{\mathrm{S}^{-}} \mathrm{CN}, \alpha_{\mathrm{S}_{2}}-\mathrm{CN}, \beta-\mathrm{LG}$, and $\alpha-\mathrm{LA}$ fractions.

\section{CONCLUSIONS}

Proteomic analysis of the effects of MTGase on the polymerization of individual milk proteins was performed. Sodium dodecyl sulfate-PAGE and 2-DE analyses showed that MTGase catalyzed $\beta-\mathrm{CN}, \kappa-\mathrm{CN}$, and a portion of the BSA, $\alpha_{\mathrm{S}_{1}-} \mathrm{CN}, \alpha_{\mathrm{S}_{2}}-\mathrm{CN}, \beta-\mathrm{LG}$, and $\alpha-\mathrm{LA}$ fractions to form high MW polymers, and that the polymerization of $\beta-\mathrm{CN}$ and $\kappa-\mathrm{CN}$ occurred earlier than that of the other milk proteins. Moreover, $\beta-\mathrm{CN}$ and $\kappa-\mathrm{CN}$ are considered excellent substrates for MTGase. A proteomics-based approach is a useful and effective method to analyze individual milk proteins affected by MTGase.

\section{ACKNOWLEDGMENTS}

We thank the National Science Council in Taiwan for grant support (NSC 98-2324-B-030-001). Proteomic 
A

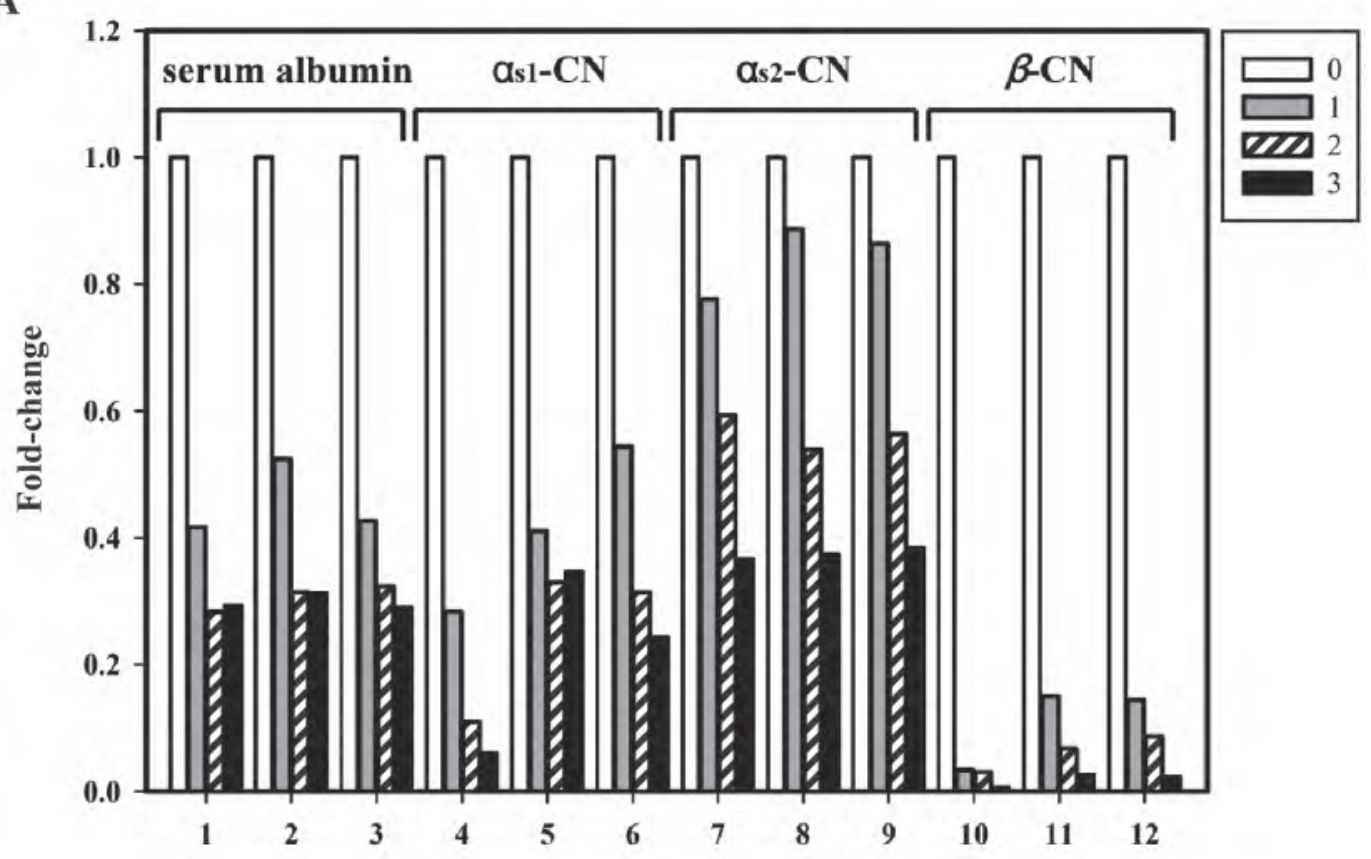

B

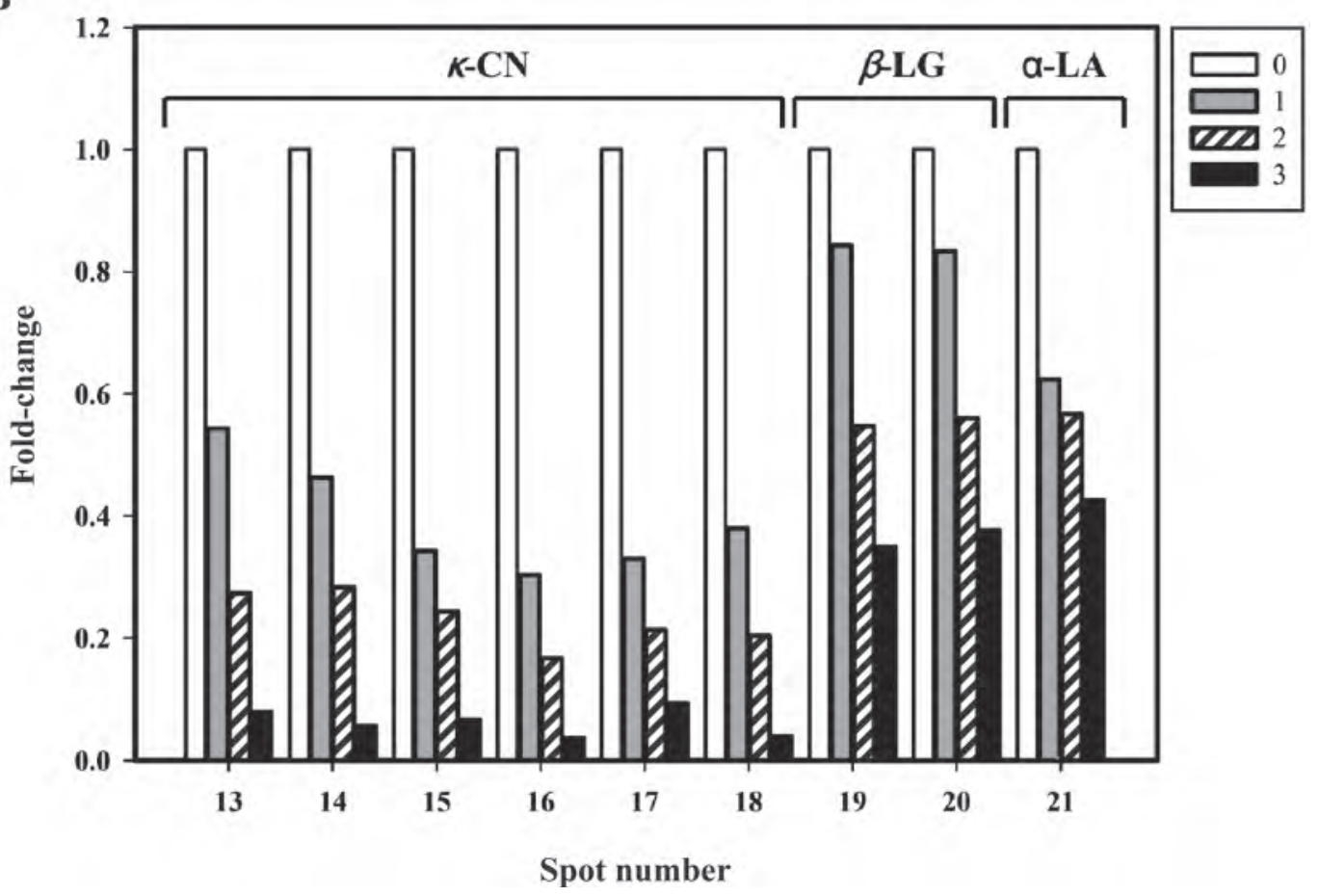

Figure 6. Relative abundance of 21 milk protein spots after treatment with microbial transglutaminase (MTGase: 2.0 units $/ \mathrm{mL}$ ) at $30^{\circ} \mathrm{C}$ for varying lengths of time $(0,1,2$, or $3 \mathrm{~h})$. (A) protein spots 1-12; (B) Protein spots 13-21. The histograms show the fold changes of the protein spots, which were determined using the PDQuest software package (Bio-Rad, Hercules, CA). Spot numbers correspond to those in Table 1. 


\section{Results of proteomic analysis of MTGase-induced polymerization of milk proteins}
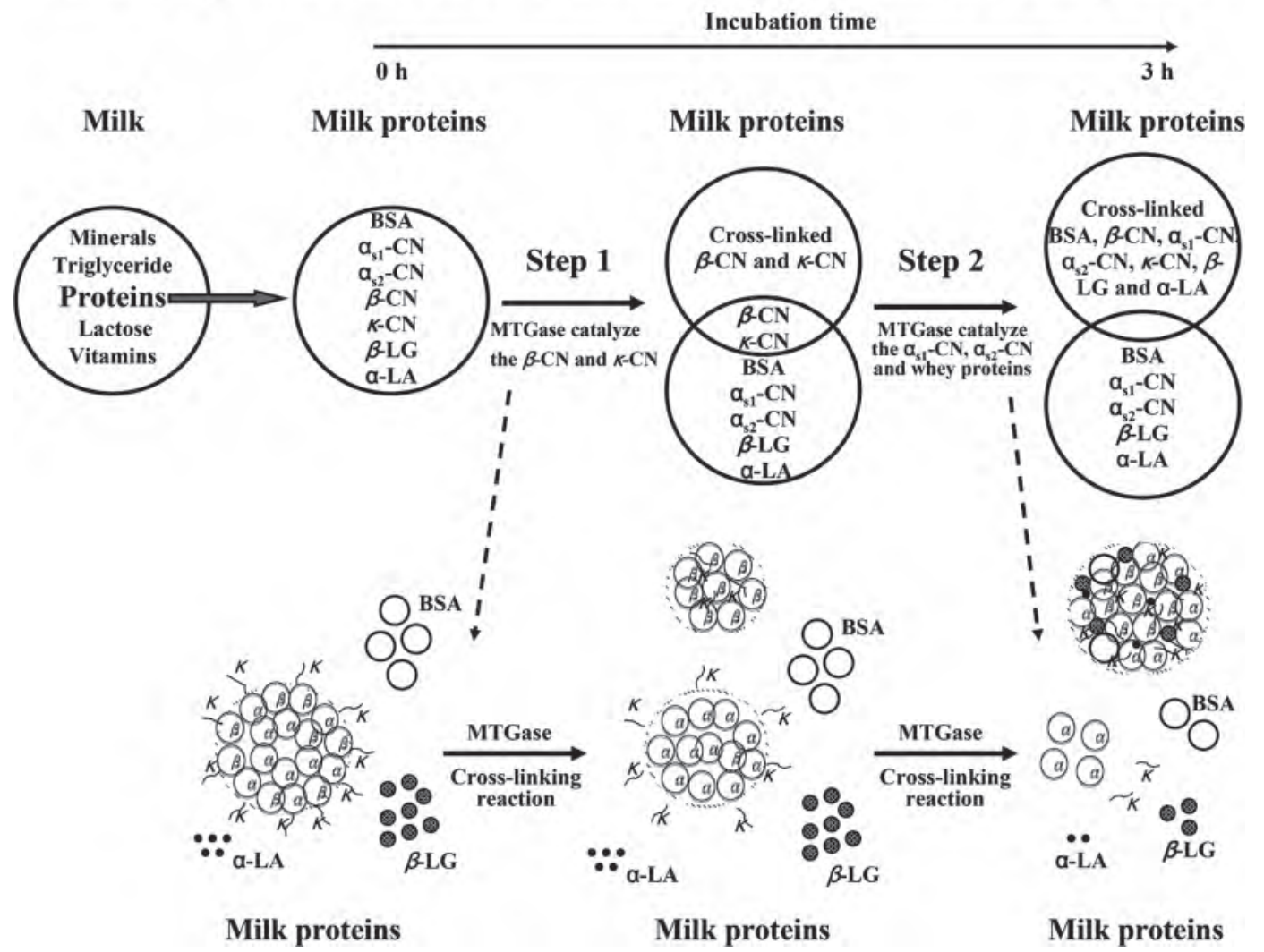

Figure 7. Reaction scheme for the effect of microbial transglutaminase (MTGase) on the polymerization of milk proteins.

mass spectrometry analyses were performed by the Core Facilities for Proteomics and Glycomics Research, which is located at the Institute of Biological Chemistry, Academia Sinica, Taiwan.

\section{REFERENCES}

Abd-Rabo, F. H. R., S. M. EI-Dieb, A. M. Abd-EI-Fattah, and S. S. Sakr. 2010. Natural state changes of cows' and buffaloes' milk proteins induced by microbial transglutaminase. J. Am. Sci. 6:612-620.

Agyare, K. K., and S. Damodaran. 2010. pH-Stability and thermal properties of microbial transglutaminase-treated whey protein isolate. J. Agric. Food Chem. 58:1946-1953.

Ahram, M., C. J. Best, M. J. Flaig, J. W. Gillespie, I. M. Leiva, R. F. Chuaqui, G. Zhou, H. Shu, P. H. Duray, W. M. Linehan, M. Raffeld, D. K. Ornstein, Y. Zhao, E. F. Petricoin, and M. R. Emmert-Buck. 2002. Proteomic analysis of human prostate cancer. Mol. Carcinog. 33:9-15.

Bahrman, N., L. Negroni, O. Jaminon, and J. L. Gouis. 2004. Wheat leaf proteome analysis using sequence data of proteins separated by two-dimensional electrophoresis. Proteomics 4:2672-2684.

Barrabés, S., A. Sarrats, E. Fort, R. De Llorens, P. M. Rudd, and R. Peracaula. 2010. Effect of sialic acid content on glycoprotein pI analyzed by two-dimensional electrophoresis. Electrophoresis 31:2903-2912.

Berggren, K., E. Chernokalskaya, T. H. Steinberg, C. Kemper, M. F. Lopez, Z. Diwu, R. P. Haugland, and W. F. Patton. 2000. Background-free, high sensitivity staining of proteins in one- and two-dimensional sodium dodecyl sulfate-polyacrylamide gels using a luminescent ruthenium complex. Electrophoresis 21:2509-2521.

Bönisch, M., T. Heidebach, and U. Kulozik. 2007. Influence of transglutaminase protein cross-linking on the rennet coagulation of casein. Food Hydrocoll. 22:288-297.

Chevalier, F., C. Hirtz, N. Sommerer, and A. L. Kelly. 2009. Use of reducing/nonreducing two-dimensional electrophoresis for the study of disulfide-mediated interactions between proteins in raw and heated bovine milk. J. Agric. Food Chem. 57:5948-5955.

Czernicka, M., J. Domagala, M. Sady, and I. Wieteska. 2009. Functional properties of milk proteins modified by transglutaminase depending on incubation conditions with the enzyme. Biotechnol. Anim. Husb. 25:737-743.

De Jong, G. A. H., and S. J. Koppelman. 2002. Transglutaminase catalyzed reactions: Impact on food applications. J. Food Sci. 67:2798-2806.

de Kruif, C. G., and C. Holt. 2003. Casein micelle structure, functions, and interactions. Pages 233-270 in Advanced Dairy Chemistry-1. Proteins. Part A. P. F. Fox and P. L. H. McSweeney, ed. Kluwer Academic/Plenum Publishers, New York, NY.

Elshereef, R., H. Budman, C. Moresoli, and R. L. Legge. 2010. Monitoring the fractionation of a whey protein isolate during dead-end membrane filtration using fluorescence and chemometric methods. Biotechnol. Prog. 26:168-178.

Gagnaire, V., J. Jardin, G. Jan, and S. Lortal. 2009. Proteomics of milk and bacteria used in fermented dairy products: From qualitative to quantitative advances. J. Dairy Sci. 92:811-825.

Garcia, Y., R. Collighan, M. Griffin, and A. Pandit. 2007. Assessment of cell viability in a three-dimensional enzymatically cross-linked collagen scaffold. J. Mater. Sci. Mater. Med. 18:1991-2001. 
Gerber, U., U. Jucknischke, S. Putzien, and H. L. Fuchsbauer. 1994. A rapid and simple method for the purification of transglutaminase from Streptoverticillium mobaraense. Biochem. J. 299:825-829.

Gygi, S. P., and R. Aebersold. 2000. Mass spectrometry and proteomics. Curr. Opin. Chem. Biol. 4:489-494.

Holland, J. W., H. C. Deeth, and P. F. Alewood. 2004. Proteomic analysis of $\kappa$-casein micro-heterogeneity. Proteomics 4:743-752.

Holland, J. W., H. C. Deeth, and P. F. Alewood. 2005. Analysis of $O$-glycosylation site occupancy in bovine kappa-casein glycoforms separated by two-dimensional gel electrophoresis. Proteomics 5:990-1002.

Holland, J. W., R. Gupta, H. C. Deeth, and P. F. Alewood. 2011. Proteomic analysis of temperature-dependent changes in stored UHT milk. J. Agric. Food Chem. 59:1837-1846.

Hsieh, J. F., and S. T. Chen. 2008. A functional proteomic approach to the identification and characterization of protein composition in wheat leaf. Curr. Proteomics 5:253-266.

Huppertz, T., and C. G. de Kruif. 2007. Ethanol stability of casein micelles cross-linked with transglutaminase. Int. Dairy J. 17:436441.

Lee, D. S., S. Matsumoto, Y. Matsumura, and T. Mori. 2002. Identification of the $\varepsilon$ - $(\gamma$-glutamyl)lysine cross-linking sites in $\alpha$-lactalbumin polymerized by mammalian and microbial transglutaminases. J. Agric. Food Chem. 50:7412-7419.

Lorenzen, P. C., H. Neve, A. Mautner, and E. Schlimme. 2002. Effect of enzymatic cross-linking of milk proteins on functional properties of set-style yoghurt. Int. J. Dairy Sci. Technol. 55:152-157.

Matsumura, Y., D. S. Lee, and T. Mori. 2000. Molecular weight distributions of $\alpha$-lactalbumin polymers formed by mammalian and microbial transglutaminases. Food Hydrocoll. 14:49-59.

Monogioudi, E., N. Creusot, K. Kruus, H. Gruppen, J. Bucher, and M. L. Mattinen. 2009. Cross-linking of $\beta$-casein by Trichoderma reesei tyrosinase and Streptoverticillium mobaraense transglutaminase followed by SEC-MALLS. Food Hydrocoll. 23:2008-2015.

Moon, J. H., Y. H. Hong, T. Huppertz, P. F. Fox, and A. L. Kelly. 2009. Properties of casein micelles cross-linked by transflutaminase. Int. J. Dairy Sci. Technol. 62:27-32.
Morris, G. A., T. J. Foster, and S. E. Harding. 2000. Further observations on the size, shape, and hydration of casein micelles from novel analytical ultracentrifuge and capillary viscometry approaches. Biomacromolecules 1:764-767.

Morrissey, B., and K. M. Downard. 2006. A proteomics approach to survey the antigenicity of the influenza virus by mass spectrometry. Proteomics 6:2034-2041.

O'Connell, J. E., and P. F. Fox. 2000. The two-stage coagulation of milk proteins in the minimum of the heat coagulation time-pH profile of milk: Effect of casein micelle size. J. Dairy Sci. 83:378-386.

O'Donnell, R., J. W. Holland, H. C. Deeth, and P. Alewood. 2004. Milk proteomics. Int. Dairy J. 14:1013-1023.

O'Sullivan, M. M., A. L. Kelly, and P. F. Fox. 2002. Effect of transglutaminase on the heat stability of milk: A possible mechanism. J. Dairy Sci. 85:1-7.

Ong, S. E., and A. Pandey. 2001. An evaluation of the use of twodimensional gel electrophoresis in proteomics. Biomol. Eng. 18:195-205.

Pisano, A., N. H. Packer, J. W. Redmond, K. L. Williams, and A. A. Gooley. 1994. Characterization of $O$-linked glycosylation motifs in the glycopeptide domain of bovine kappa-casein. Glycobiology 4:837-844.

Sharma, R., P. C. Lorenzen, and K. B. Qvist. 2001. Influence of transglutaminase treatment of skim milk on the formation of $\varepsilon-(\gamma$ glutamyl)lysine and the susceptibility of individual proteins towards crosslinking. Int. Dairy J. 11:785-793.

Smiddy, M. A., J. E. Martin, A. L. Kelly, C. G. de Kruif, and T. Huppertz. 2006. Stability of casein micelles cross-linked by transglutaminase. J. Dairy Sci. 89:1906-1914

Tang, C. H., and C. Y. Ma. 2007. Modulation of the thermal stability of $\beta$-lactoglobulin by transglutaminase treatment. Eur. Food Res. Technol. 225:649-652. 